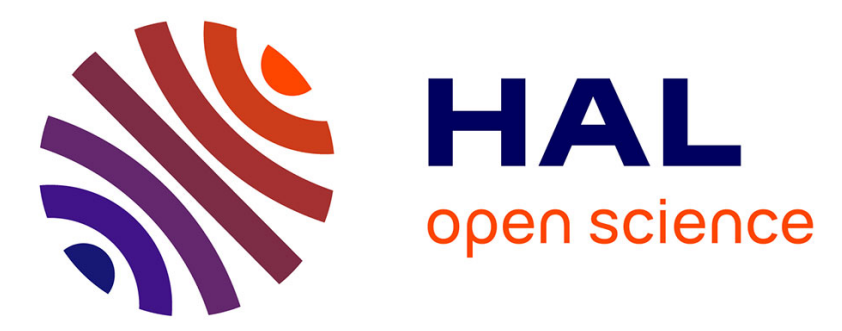

\title{
Analyzing the Distribution of Population-Based Employment in France
}

Jean-Christophe Dissart, Francis Aubert, Denis Lépicier

\section{To cite this version:}

Jean-Christophe Dissart, Francis Aubert, Denis Lépicier. Analyzing the Distribution of PopulationBased Employment in France. Regional Studies, 2011, 46 (9), pp.1. 10.1080/00343404.2011.559218 . hal-00694720

\section{HAL Id: hal-00694720 \\ https://hal.science/hal-00694720}

Submitted on 6 May 2012

HAL is a multi-disciplinary open access archive for the deposit and dissemination of scientific research documents, whether they are published or not. The documents may come from teaching and research institutions in France or abroad, or from public or private research centers.
L'archive ouverte pluridisciplinaire HAL, est destinée au dépôt et à la diffusion de documents scientifiques de niveau recherche, publiés ou non, émanant des établissements d'enseignement et de recherche français ou étrangers, des laboratoires publics ou privés. 


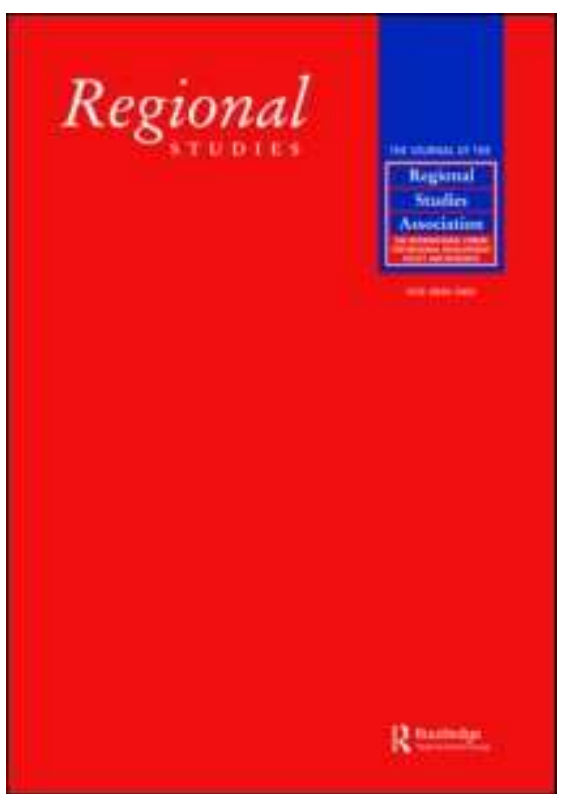

\section{Analyzing the Distribution of Population-Based Employment in France}

\begin{tabular}{|r|l|}
\hline Journal: & Regional Studies \\
\hline Manuscript ID: & CRES-2009-0307.R2 \\
\hline Manuscript Type: & Main Section \\
\hline JEL codes: & $\begin{array}{l}\text { R12 - Size and Spatial Distributions of Regional Economic Activity }< \\
\text { Economics, R15 - Econometric and Input-Output Models|Other } \\
\text { Models < R1 - General Regional Economics < R - Urban, Rural, and } \\
\text { Regional Economics }\end{array}$ \\
\hline Keywords: & $\begin{array}{l}\text { population-based economy, services, tourism, location factors, } \\
\text { France }\end{array}$ \\
\hline
\end{tabular}

\section{SCHOLARONE" Manuscripts}




\title{
Cris: note that the authors provided the French abstract
}

Analyzing the Distribution of Population-Based Employment in

\section{France $^{1}$}

\author{
Jean-Christophe DISSART*, Francis AUBERT $\dagger$ and Denis LÉPICIER $\dagger$ \\ *Cemagref Grenoble (UR DTM), 2 rue de la Papeterie, BP 76, 38402 Saint-Martin-d'Hères \\ Cedex, France. Email: jean-christophe.dissart@ cemagref.fr \\ $†$ INRA-Agrosup (UMR CESAER), 26 bd Docteur Petitjean, BP 87999, 21079 Dijon Cedex, \\ France. Emails: francis.aubert@enesad.inra.fr and denis.lepicier@enesad.inra.fr
}

(Received October 2009: in revised form January 2011) 


\begin{abstract}
The objective of this paper is to analyze the spatial distribution of employment in population-based services across metropolitan France. The population-based economy comprises services that satisfy the demand of both the permanent (residing) and temporary (tourists and day travelers) population. Using spatial regression and shift-share analysis at the functional economic area scale, several categories of location factors are studied: market potential, the propensity to consume locally as well as local attractiveness and access to facilities. Results identify structural and geographic factors related to local demand and show that the distribution of employment follows an urban-rural gradient except in periurban and tourism areas.
\end{abstract}

Keywords: population-based economy; services; tourism; location factors; France

Titre: Analyser la distribution de l'emploi résidentiel en France

Résumé: L'objectif de cet article est d'analyser la distribution spatiale de l'emploi dans les services à la population en France métropolitaine. L'économie résidentielle regroupe des services qui satisfont la demande d'une population à la fois permanente (résidente) et temporaire (touristes et excursionnistes). Plusieurs types de facteurs de localisation sont étudiés, au niveau des bassins de vie, à l'aide de la régression spatiale et de l'analyse structurelle-géographique : potentiel de marché, propension à consommer localement ainsi qu'attractivité locale et accès aux équipements. Les résultats identifient des facteurs structurels et géographiques liés à la demande locale et montrent que la distribution de l'emploi suit un gradient urbain-rural sauf dans les espaces périurbains et touristiques. 
Mots clés: économie résidentielle; services; tourisme; facteurs de localisation; France

JEL classifications: R12, R15

\section{INTRODUCTION AND LITERATURE REVIEW}

The increasing weight of the tertiary sector in the national economy has ambiguous economic geography impacts. On the one hand, the development of services to businesses tends to reinforce the concentration of production activities; on the other hand, the development of services to households tends to distribute those services as close as possible to the population. Since the European population is increasingly locating outside major cities and employment centers, taking account of the population-based economy is becoming a critical issue in terms of regional development and territorial cohesion (CEC, 2008). In addition to this counterurbanisation flow that favors periurban areas, there is a demographic surge in more remote areas, which results from people's increasing interest for the environment and attractive residential settings and consequently augments the demand for population-based services.

More specifically, from a regional economics perspective, the increasing share of services in the economy tends to result in a spatial homogenization of location mechanisms at the European scale (DIACT, 2009). Services tend to spread spatially (HOUDEBINE, 1999; MIDELFART-KNARVIK et al., 2000), or at least they do not contribute to the concentration of activities (GAULIER, 2003). However the location of services varies by service type and particularly with respect to tradability and knowledge intensity. Indeed, financial services and 
services to businesses are more sensitive to agglomeration and spatial concentration, whereas retail trade and transportation services are more scattered (JENNEQUIN, 2008).

In location theory, economic activities are spatially dependent upon both economies of scale (agglomeration) and transportation costs (accessibility). The former increase agglomeration effects all the more that differentiation limits competition and externalities further increasing returns. The latter tend to increase dispersion, especially if population density is low and production activities use fixed assets. Economic geography's formal framework addresses regional effects of farming and manufacturing activity dynamics, and underlines the dominant character of dispersion forces for the former and agglomeration forces for the latter. As such, the location of tertiary activities is seldom directly addressed, but may be explained by distinguishing two categories of tertiary goods: firm- or householdrelated.

First, services to firms may be considered intermediate goods that are used by manufacturing activities. Their location is related to the industrial sector's by upstream relationships (VENABLES, 1996). Consequently, business service firms reinforce the cumulative process that tends to concentrate activities in central places (JENNEQUIN, 2005). Second, because they are little tradable, the location of services to households follows the distribution of demand, and consumers of population-based services are mostly located in their region of residence. Consequently, from a location theory perspective, such services are part of spatial structures that depend upon household location, i.e. consumers. Conversely, the distribution of households conditions market potential, which contributes to the concentration of services (though households bear transportation costs).

In addition, both observation and economic analysis of migration underline the sensitivity of households to environmental and amenity factors in their residential location decision making process (McGRANAHAN, 2008). Though the geographic concentration of 
employment in cities tends to remain stable or even increase, households tend to choose residential locations that are increasingly distinct and away from employment centers, thus contributing to urban sprawl. Such dynamics are significant in North American and European rural areas. Reducing the household transportation constraint increases location possibilities to satisfy a preference for a non-urban living environment (even for the active workforce with a job located in the urban center). The role of amenities, i.e. factors that are fixed and not tied to production activity but to residential attractiveness, is thereby strengthened, and localized demand becomes a household dispersion factor.

The disconnection between place of residence and place of work results in daily commutes for the employed workforce, thus underlining the trip function of households whose microeconomic basis is given by consumer theory applied to trip decisions (NIEDERCORN and BECHDOLT, 1969). Consumers seek to maximize the utility function of their trips. For a given origin, the utility of trips to a potential destination increases as a function of foreseeable contacts. Consequently, consumption behavior for population-based services is related to both the geographic distribution of services and commuting behavior with respect to, among others, place of work or recreation activities. Multiple-destination trips then become a critical factor for grouping services in some places, thus yielding gravitational phenomena. Consequently, in a given area, the agglomerated population plays a critical role in the location of population-based services. These services follow the spatial distribution of related expenditures, whether made by the local or the outside population. This relation holds for market services but is probably more complex for public or highly administered services. The location of the latter depends on both market factors and spatial planning policies that are also guided by criteria of accessibility and equity of access for all citizens regardless of their place of residence. 
Overall, this paper has two objectives: to present the spatial distribution of populationbased services across metropolitan France, and to explain their distribution by household localized demand. The geography of such services is not well known and methodologically tricky due to scarce data and lack of common statistical conventions. In this paper, population-based services are defined as non tradable, tertiary final goods that satisfy household localized demand. ${ }^{2}$ Following location theory, which emphasizes market potential and propensity to consume locally as explanatory dimensions, this paper combines market area analysis and territorial analysis to understand distribution patterns of population-based employment in both urban and more outlying areas. Using spatial regression and shift-share techniques, the analysis is done at the Functional Economic Area (FEA, bassin de vie) scale, which takes into account both household location at the municipality scale and commuting patterns. Therefore, the distribution of population-based services is a function of local potential demand, be it permanent or temporary; tourist (temporary) demand is assumed to complement resident (permanent) demand.

The paper is organized as follows. Data and methods are detailed in the next section. Section 3 presents employment density results in both population-based services and tourism services at the FEA scale. The explanatory power of local demand variables is also assessed, and regional differences in the location of population-based services are further analyzed. The conclusion sums up the main results and confirms the critical role of agglomeration factors but also underlines the dispersing role of fixed assets (which impact tourism destinations) and government decisions (which impact the provision of specific services).

\section{DATA AND METHODS}




\section{Units of analysis and spatial typologies}

The geographic scale of analysis for the study is the Functional Economic Area (FEA). FEAs have been used in several European research contexts, including Sweden (KARLSSON and OLSSON, 2006), the Netherlands (CÖRVERS et al., 2009), and France (SCHMITT et al., 2006). Here an FEA (bassin de vie) is the smallest region in which the (permanent) resident population has access to both jobs and the facilities it needs for everyday life (INSEE, 2003). Such facilities comprise four categories: 1) market facilities (e.g. retail stores, banks), 2) nonmarket facilities (e.g. police, retirement homes, post office, sports facilities), 3) health facilities (e.g. physicians, nurses, hospitals), and 4) education facilities (e.g. primary, high schools). There are 1,916 such sub-regional areas that cover metropolitan France, the majority of which $(1,745)$ are structured around small towns with less than 30,000 inhabitants.

The analysis uses two spatial classification systems: ZAUER and tourism zones. The ZAUER (Zonage en Aires Urbaines et aires d'emploi de l'Espace Rural) classification system divides metropolitan France in two major categories: rural-dominant or urban-dominant. The rural-dominant space comprises both small urban units and rural municipalities; the urbandominant space is further divided into urban poles, periurban rings (all urban area municipalities except the urban pole), and other periurban municipalities (whose residents commute to several urban areas). Based on both job numbers and commuting patterns, the ZAUER classification of municipalities was adapted to fit FEAs (using the main municipality's position in that typology) and define four spatial categories (urban pole, periurban, rural job pole, and other rural FEAs).

On the other hand, tourism zones are defined on the basis of both geographic context (as defined by the tourism industry: coast, mountain, mountain resort, rural or urban) and municipalities' lodging capacity. For instance, a functional economic area is considered part of the "coast" tourism zone if, among all municipalities that make up the FEA, the greatest 
lodging capacity is found in municipalities that belong to the "coast" category identified by tourism professionals.

\section{Defining the scope of population-based services}

"Population-based services" is not a standard category of economic activity classification systems. This set of services is usually associated with the trade and transportation sectors to make up the tertiary sector, which is further differentiated into market (e.g. retailing, real estate, finance) and non-market (e.g. education, health, public administration) services. A second classification criterion is between household- and firm-related demand, and the literature has tended to focus on the latter (see e.g. HOYLER et al., 2008; SOKOL et al., 2008). INSEE's work on FEAs suggests yet another classification of activities: those that mainly satisfy the needs of the local population (residential sector) vs. those that contribute to the production of goods and services meant for a greater market area than the local market (productive sector).

In this paper population-based services relate to activities that satisfy the needs of the population. Since the distinction between household and firm demand is not systematically easy to make, the analysis by DE SEZE and ARMAND (2005) is also used. They calculate the coefficient of variation of the density of employment in service activities per inhabitant to identify the related final demand. A low coefficient of variation, which means a fairly homogenous distribution of employment, is a salient feature of population-based services; whereas activities that are not directly related to population density are characterized by high coefficient of variation values and are excluded from the analysis. Examples of the latter include reinsurance, financial intermediation, film production or labor union activities.

In conclusion, population-based services comprise final tertiary goods production activities, i.e. services that directly satisfy the needs of the population (permanent or 
temporary). This definition is restrictive with respect to such production activities as construction, energy, or firm-related services (which are excluded from the analysis); but inclusive regarding public services, which are overwhelmingly included in the study. Thus, population-based services comprise diverse activities and jobs, both in the public and the private sectors, both market and non-market in nature, and sensitive to different location factors. Therefore, the set of population-based services is broken down into four sub-groups that are commonly used as intermediate-level aggregations of activities: 1) retailing; 2) market services (hotels, restaurants, transportation, financial and real estate activities, recreation activities, personal services); 3) administered services (postal mail and telecommunication, education, health and social services, associations); and 4) government services. The detailed list of study economic sectors is available from the authors at three increasingly disaggregated French classification systems: NES 36, NES 114 and NAF 700.

\section{Estimating tourism employment}

As listed by the French Ministry of Tourism and following the NAF 700 nomenclature, tourism-sensitive activities include (MDT, INSEE, 2005): lodging (tourism hotels with a restaurant [551A], tourism hotels without a restaurant [551C], other hotels [551E], youth hostels [552A], campgrounds [552C], and other tourism lodging [552E]); restaurants and cafés (traditional restaurants [553A], fast-food restaurants [553B], cafés tabacs [554A], and bars [554B]); and other activities (cable cars and ski lifts [602C], travel agencies [633Z], beauty salons [930E], spa and thalassotherapy activities [930K], and other body care [930L]).

Using this definition, there is a risk of overestimation of tourism employment because all employment in these 15 sectors is not related to tourism. Indeed, as much as jobs in hotels may be considered fully dependent on tourists, jobs in cafes and restaurant also depend upon the local population. But there is also a risk of underestimation because this list does not take 
account of other sectors that are impacted by tourism activity. For example, to some extent jobs in retailing are impacted by temporary residents (tourists and day travelers).

In this paper, the estimation of tourism employment using the minimum requirements technique (DISSART et al., 2009; ENGLISH et al., 2000; LEATHERMAN and MARCOUILLER, 1996) aims at both taking account of all tourism-related activities (in addition to the above-listed 15 sectors) and counting tourism-related employment only. This approach states that within groups of homogenous regions from a demand perspective, the region that presents the minimum number of population-based employment per inhabitant is considered satisfying the needs of the permanent resident population only. Then, within this group, all population-based job values that are higher than this minimum value are considered satisfying the needs of the temporary resident population; it is assumed such demand corresponds mostly to tourism and recreation demand. Consequently, applying this method requires several steps: creating groups of homogeneous FEAs from a population-based demand perspective; calculating the minimum requirements value in each group; and estimating tourism employment in each FEA. It is further assumed that tourism employment is mostly related to the market service sector, which implies that tourism employment is a subset of retailing and market service activities, thereby excluding administered and government services.

Consistent with explanatory variables of the density of population-based services (see below), the typology of functional economic areas is based on market potential and household propensity to consume locally, with five clustering criterion variables: 1) income; 2) market size; 3) proportion of blue-collar workers and 4) retirees; and 5) commuting. Because of measurement unit differences, variables are standardized (mean 0, standard deviation 1) and their level of correlation analyzed. The clustering algorithm is a k-means method and the final number of clusters is decided using several empirical criteria $\left(\mathrm{R}^{2}\right.$ included). Then, as the 
minimum value in a given cluster may actually be an outlier and since there is no theoretical justification for using systematically the minimum value (KLOSTERMAN, 1990), the 10th percentile value is used, a choice that also reflects the objective to get a moderate estimation of tourism employment density in functional economic areas.

\section{Variables of population-based and tourism employment density}

The dependent variables are, on the one hand, number of jobs in population-based services per 1,000 inhabitants (POP_BASED) and its sub-categories regarding retailing and market services (RET_MKT) and administered and government services (ADM_GOV); and on the other hand, number of jobs in tourism-related services (i.e. in trade and market services as estimated by the minimum requirements technique) per 1,000 inhabitants (TOURISM). The choice of employment density as a dependent variable is critical. Indeed, first, it is assumed location factors of employment in services are better analyzed using a density perspective. Second, by choosing employment, availability of data is ensured, thus enabling an analysis of the distribution of services across metropolitan France. Third, numbering jobs does not, however, account for issues of establishment location and labor productivity. Unless otherwise noted, all data are for the year 1999, which corresponds to the latest population census available at the time of this research, and do not distinguish part-time or seasonal jobs from full-time employment.

Explanatory variables of population-based employment measure the two dimensions that impact such employment, i.e. market potential and the propensity to consume locally: market size (MKT_SIZE), income (INCOME), consumption structure as estimated by the proportion of blue-collar workers (BLUE_COL) and retirees (dropped because of correlation with INCOME), potential for temporary attendance as proxied by lodging capacity 
(LODG_CAP), and (daily work-residence) commuting (COMMUT_IN, COMMUT_OUT, COMMUTE). Details and descriptive statistics for these variables are found in Table 1.

\section{TABLE 1 HERE}

The independent variables assumed to influence the level of tourism employment (TOURISM), hence its distribution across metropolitan France, include potential for temporary attendance (LODG_CAP), fiscal potential, accessibility (ACCESS), population density, nature-based sports facilities, farm and agrifood employment, manufacturing employment, and natural amenities. The fiscal potential variable (FISC_POT) is the sum of local direct taxes (lodging, business, developed land, undeveloped land), each multiplied by its average national rate, then divided by the number of inhabitants; it proxies a capacity for action at the multimunicipal scale to finance public infrastructure. The accessibility variable measures the average distance (in minutes) to the closest urban pole. The population density variable (POP_DEN) is also an indicator of the built environment (because of high correlation with artificial surfaces), of tourism attendance (e.g. man-made heritage, museums), and access to services (fast food, etc.). The sports facilities variable (NAT_SPORT) focuses on naturebased activities (e.g. hiking trail, via ferrata, canyoning) that use local natural resources and are more likely to attract external households than other facilities (e.g. soccer fields) that are more directly related to meeting the needs of the local permanent population. The density of employment in farming and agrifood activities (FARM_AGRIF) reflects a potential positive amenity in terms of landscape maintenance, economic activity support, and more generally rural life; whereas the density of employment in industrial activities (MANUFACT) rather reflects a potential negative amenity because such activities may be negatively perceived in terms of landscape and pollution. 
Last, the natural amenity variable (NAT_AMEN) is an index consistent with McGRANAHAN (1999) that uses two climate and two landscape feature variables: 1) proportion of water areas (wetland and water body surfaces divided by total FEA area); 2) topographic variation (difference between the FEA maximum altitude and that of the FEA's main municipality's city hall); 3) warm winter (average January temperature); 4) wet summer (average number of July rainy days); the index is simply the sum of the 4 variables, capped for extreme values and standardized $(0,1)$. From a tourism perspective, this index is likely to offer an incomplete description of amenities because they cover a wide range of features that simply cannot be all captured by 4 variables that explicitly exclude built attributes. For more complete (but not without limitations) definitions, see DELLER (2010) or MARCOUILLER et al. (2004). In particular, the latter use principal component analysis to combine 43 amenity variables (both natural and facility attributes) into 5 tourism-related (land, river, lake, warm weather and cold weather) dimensions. Nonetheless our analysis controls for a subset of tourism-related built attributes (NAT_SPORT).

\section{Methods}

Data on FEA features and employment density are used to analyze the location factors of employment in both population-based and tourism-related services. In addition to descriptive statistics, cluster analysis and the minimum requirements technique (to estimate tourism employment density), two statistical methods are used successively.

First, spatial regression is used to identify FEA structural characteristics that impact the density of employment in population-based and tourism services. Indeed, the data used in the analysis are explicitly spatial, so it is not unexpected that the location of an FEA has an effect on population-based employment. In other words, it is likely spatial autocorrelation occurs, which means that classic Ordinary Least Squares (OLS) estimators are unbiased but 
inefficient and the estimates of the variance of the estimators are biased, thereby impacting the precision of the estimates and the reliability of hypothesis testing (DUBIN, 1998). Moran's I tests confirmed that all OLS models present statistically significant $(\mathrm{p}<0.01)$ spatial autocorrelation so we estimate the following spatial autoregressive model with spatial error dependence (ANSELIN, 1988; LE GALLO, 2002):

$$
y=\rho W_{1} y+X \beta+\varepsilon ; \quad \varepsilon=\lambda W_{2} \varepsilon+u ; \quad u \approx N\left(0, \sigma^{2} I\right)
$$

where $y$ is the $(N, 1)$ vector of dependent variable observations, $\rho$ is the spatial autoregressive parameter for the dependent variable, $W$ denotes a spatial weight matrix, $X$ is the $(N, K)$ matrix of explanatory variable observations, $\beta$ is the $(K, 1)$ vector of unknown regression coefficients, $\varepsilon$ is the $(N, 1)$ vector of spatially autocorrelated error terms, $\lambda$ is the spatial autoregressive parameter for the disturbance $\varepsilon$, and $u$ is the $(N, 1)$ vector of identically and independently distributed errors with zero expectation and $\sigma^{2}$ variance ( $I$ is the identity matrix).

The models are estimated by Maximum Likelihood (ML) using several spatial weight (contiguity and distance) configurations. Lagrange multiplier tests for $\rho$ and $\lambda$ are used to check model specification. The specification of tourism regression models excludes the independent variables used for clustering functional economic areas because their effect has already been taken into account to estimate tourism employment.

Second, shift-share analysis is used to identify geographic factors that may be associated with specific regional dynamics. By geographic we mean factors that are independent of FEAs' structural characteristics and may be linked to territorial specificity. The method is based on the following classic equality (BERZEG, 1978; JAYET, 1993):

$$
r_{j}=r+s_{j}+g_{j}
$$

where $r_{j}$ is employment density in region $j, r$ is employment density national average, $s_{j}$ is the structural effect, and $g_{j}$ is the geographic effect. 


\section{Employment density in population-based and tourism services}

As defined in this paper, population-based services comprise a total of 11.5 million jobs $(11,480,056)$, i.e. $50 \%$ of total employment in 1999 (22,800,731). As compared with other activity typologies, this figure is close to INSEE's "residential economy" estimation at the FEA scale $(12,936,593)$, and lower than the tertiary employment estimation in the classic sectoral breakdown $(16,378,354$ in addition to primary and secondary sector employment) thus confirming the somewhat restrictive scope of this analysis.

These jobs are mostly located in urban centers (over 75\%) that comprise $61 \%$ of the population, and particularly in the biggest cities (about 2 out of 3 population-based jobs are located in urban areas over 200,000 inhabitants except Paris). The Paris urban area itself comprises 2.4 million jobs in population-based services, i.e. $20 \%$ of national employment in this sector (vs. $16 \%$ of the population). Then, periurban areas rank second with over 1.2 million jobs. Rural areas comprise less than 1 out of 6 jobs to meet the needs of less than $20 \%$ of the population; population-based services are particularly concentrated in rural poles (i.e. rural towns and their proximate periphery). 
Among population-based services, administered services (education, health, associations, postal service) represent by far the highest share of jobs (45\%). Retailing and market services rank second (43\%), followed by government services (1.6 million jobs). The balance between market services at large (i.e. including retailing) and administered and government services is relatively constant across space. Paris is unique because market service jobs are almost as numerous as administered and government jobs. In contrast, administered and government jobs tend to be more important in other urban poles, particularly in small- and medium-sized cities.

At the FEA scale, there is an average of 6,000 population-based jobs in French FEAs, and employment is strongly linearly correlated $\left(\mathrm{R}^{2}=0.93\right)$ with the number of (permanent) residents. Outside Paris, urban FEAs comprise an average of 20,000 population-based jobs. With an average of 1,935 population-based jobs, rural pole FEAs are very different from periurban FEAs (an average of 1,341 jobs, but with greater variability), though the latter present similar population levels (11-13,000 inhabitants) and exhibit the highest population growth rate (close to $1 \%$ per year between 1990 and 1999). However, the growth in population-based salaried employment was strongest in periurban areas over the 1999-2005 period $(2.22 \%$ vs. $1.81 \%$ at best in other spatial categories), which may indicate that a convergence process in terms of facilities and services is at work in these areas. With fewer than 800 population-based jobs, other rural FEAs seem very small-sized rural markets.

In terms of employment density, on average, the density of population-based services is 150 jobs per 1,000 permanent residents but there is great variation depending on the spatial category of the functional economic area (Table 2). FEAs structured around urban poles feature an average density that is almost twice higher than in periurban municipalities (195 and 116 jobs per 1,000 inhabitants, respectively). This gap is even greater for the largest urban areas, as exemplified by Paris with an average density that is $61 \%$ higher than the 
national average. Rural areas exhibit a higher density of population-based services than periurban areas (around 150 jobs per 1,000 inhabitants), thus showing their greater ability to satisfy the needs of their residing population. Moreover, there is little difference between rural poles vs. other rural FEAs.

\section{TABLE 2 HERE}

Figure 1 shows that FEAs with low job densities in population-based services are often close to urban poles; such FEAs are mostly located in the northern part of France, from Brittany to Alsace. Functional economic areas with high job densities ( $>250$ ) correspond to urban poles (e.g. Caen, Rennes, Vannes, Dijon, Besançon) and significant tourism areas (the Alps in particular).

\section{FIGURE 1}

The estimation of tourism employment using the minimum requirements technique applied to structurally homogeneous clusters of functional economic areas yields a total value of $1,486,794$ tourism jobs, i.e. $13 \%$ of all population-based service jobs. This estimation is higher than BACCAÏNI et al.'s (2006) -894,500 jobs in 2003- but not inconsistent. Indeed, the latter is based upon more precise data (DADS) but limited to salaried employment, whereas this paper's estimation includes sole proprietorships and uses a different method. INSEE's yearly survey of service firms gives average values for salaried and non-salaried employment in tourism sensitive activities. Using these figures, a ratio of non-salaried to total employment of $21 \%$ (in 2003) may be calculated. Applying this ratio to BACCAÏNI et al.'s (2006) 
estimation, we get a non-salaried employment figure of 186,281 for a total employment figure of $1,080,781$, thereby bringing the two estimations closer.

This estimation of tourism employment corresponds to an average density of 25 tourism jobs per 1,000 inhabitants (Table 2), i.e. an average of one sixth of total populationbased service employment in functional economic areas. As expected, tourism employment density is less related to the FEA's spatial position along the urban-rural gradient. Indeed, on average, tourism employment density values are similar or even higher in rural area vs. urban pole FEAs. Paris presents a unique situation given its strong tourism attractiveness (as a worldwide tourism destination).

The highest densities of tourism employment are mostly found in Paris and in coastal and mountain areas and more generally in southern France (including Corsica, see Figure 2). To a significant extent this result matches tourism lodging capacity (number of beds in second homes, hotels and campgrounds) which is also mainly located in coastal and mountain (resort) areas. Higher-than-average tourism employment densities (25-100) are observed in the hinterland of coastal and mountain areas, but also in several FEAs located in eastern France (Bourgogne, Jura) as well as southwestern France and Massif Central (Dordogne, Lot, Corrèze, Cantal, Aveyron, Lozère). The lowest densities of tourism employment are observed in the western part of France, as well as the Nord and Lorraine regions.

\section{FIGURE 2 HERE}

\section{Location factors of population-based and tourism employment}

Initial OLS estimations showed that variables of market potential and propensity to consume locally (Table 3 ) significantly explain the density of population-based employment $\left(\mathrm{R}^{2}=0.61\right.$ for all services). With a strongly significant $\lambda$ and $\rho$ (statistically) not different from 0 , final 
ML estimations show that a Spatial Error Model (SEM), with an inverse distance weight matrix (60 km distance cutoff), is the correct specification to address spatial autocorrelations issues. Moran's I statistics also show that spatially autocorrelated error structures have been removed.

Market potential variables (market size, consumption structure and potential for temporary attendance) have a strong explanatory power (Table 3). In particular, the level and/or structure of consumption in heavily blue collar FEAs is associated with a lower density of population-based employment even though the income variable is not included in the specification. The propensity to consume locally significantly impacts the density of employment, mainly via work-residence daily commutes. A greater proportion of the workforce that enters the FEA is strongly and positively associated with the density of employment in population-based services, thereby increasing FEA market size for such services; the opposite association is found for the proportion of the workforce that leaves the FEA. This result confirms the role of commuting patterns in explaining the density of population-based employment whereby central FEAs capture peripheral income (i.e. of households residing on their outskirts) that translates into local jobs. Last, as expected, the size of the FEA pole is strongly and positively associated with the density of employment.

\section{TABLE 3 HERE}

The location factors of employment in administered and government services are similar to those in retailing and market services, except for the lodging capacity variable. Indeed, attractive FEAs in terms of temporary population tend to have fewer jobs in administered and government services than other FEAs, but more jobs in retailing and market services, which confirms the mainly private sector impacts of the tourism economy. 
Moreover, household social characteristics seem to play a significant and negative role in the density of administered and government employment since a greater proportion of blue-collar households is associated with a lower density of such services. This result seems surprising given policy makers' equity objectives in terms of access to public services. It may nonetheless be explained by the relative social differentiation of functional economic areas: in general, periurban areas both provide fewer services and are more "blue-collared".

Like population-based employment models, the variation in tourism employment density is better explained by ML estimation of a spatial error model using an inverse distance weight matrix (Table 4). Analyzing the role of structural variables in tourism employment tells a two-tier story. First, a simple linear regression model with lodging capacity or fiscal potential yields a fairly high coefficient of determination value ( 0.57 and 0.54 , respectively). Therefore, the location of tourism employment is first and foremost impacted by tourist demand (which is not limited to high season because of the increasingly important role of short stays all year long) and the investment capacity of local units of government (Table 4, model 1). A feedback relationship may also be at work, i.e. tourism activity (as illustrated by tourism jobs) brings more wealth locally (following French fiscal policy, both second homes and tourism-related businesses extend the local fiscal base) and puts pressure on municipalities to have more tourism beds (i.e. increase lodging capacity) to match tourist demand.

\section{TABLE 4 HERE}

Second, other independent variables display a level of correlation with tourism employment density that is less than 0.15 . This second set of variables (Table 4 , model 2) 
addresses local attractiveness issues: accessibility (ACCESS), population density (POP_DEN), density of nature-based sports facilities (NAT_SPORT), other economic activities (FARM_AGRIF, MANUFACT), and natural amenities (NAT_AMEN). Initial OLS estimation showed that model 2 is significant overall, but the $\mathrm{R}^{2}$ drops from over $60 \%$ to $5 \%$, thereby confirming the weaker explanatory power of this alternative specification.

In model 2, only accessibility is significant and positive; employment density in both farming and agrifood processing and manufacturing is significant and negative; and density of population, density of nature-based sports facilities as well as natural amenities are not significant. In other words, and caution is in order given correlation levels between model 2 independent variables and tourism employment density, the positive sign of ACCESS indicates that remoteness positively impacts tourism activity, or at least that rural amenities counterbalance distance costs. Though questionable as a development strategy on environmental sustainability grounds, relative isolation may be considered an amenity for tourism activity. Next, there does not seem to be a production activity effect on tourism: neither farming and agrifood processing employment (though related to landscape maintenance or rural milieu support) nor manufacturing employment is positively associated with tourism employment density.

As leisure and tourism activities are typically associated with such natural resources as water, elevation or a sunny climate, the (statistical) non significance of the amenity index requires some discussion. The geographic distribution of the index tilts toward southeastern France, which combines a Mediterranean climate (i.e. mild winter temperatures and a dry summer) and coastline with mountain ranges (the Alps and some of the Massif Central). On the contrary, tourism employment is more scattered across metropolitan France, strong in the Paris area, and sensitive to resort effects in coastal and mountain areas (which are also found along the Channel and the Atlantic coasts as well as the Pyrénées). Since the two variables do 
not display the same geographic distribution, a weak statistical relation is not surprising. This might also be explained by the way the amenity index was constructed, i.e. a focus on climate and landscape feature variables which reflects a concern for the natural resource base but might give climate too great a role in explaining travel. Though the analysis controls for nature-based sports facilities, the amenity index might not sufficiently reflect specific recreational amenities that motivate the traveler.

In conclusion, lodging capacity density, and to a lesser extent fiscal potential per inhabitant, give fairly confident estimations of the density of tourism employment in a given functional economic area. Regression models with a more complete specification but not including these two variables lose much explanatory power, raising doubts about their usefulness. In particular, lodging data seem to summarize several categories of tourismrelated information: (market or non-market) lodging capacity reflects the attractiveness of a given geographic area, which results in jobs in retailing and market services related to the presence of tourists. In other words, there is lodging capacity because there are interesting resources for tourism, regardless of their nature, and these resources are sufficiently accessible and preserved to keep a significant level of tourism employment.

\section{Spatial and regional differentiation}

Shift-share analysis shows how much of the observed difference between values of the dependent variable by spatial category and its national average is explained by the geographic vs. structural variables identified in previous steps of the analysis. ${ }^{3}$ Therefore, it shows whether employment is sensitive to location (the FEA's spatial category) or not.

Density of employment in population-based services exhibits spatial sensitivity and is particularly impacted by its position on the urban-rural gradient (Table 5): the gap is 75 jobs per 1,000 inhabitants below the national average in periurban areas, minus 47 in rural job 
poles (minus 61 in other rural FEAs) and plus 21 in urban poles. Every structural variable has a statistically significant effect on the dependent variable. In particular, the balance of commutes has a negative impact in periurban and rural FEAs, as expected, but also in rural pole FEAs. Only urban FEAs benefit from the positive work-residence commuting balance. The effect of income is rather unsurprising, with a decreasing impact on the density of population-based employment along the urban-rural gradient.

\section{TABLE 5 HERE}

With a smaller magnitude, the same observation holds for lodging capacity. Lodging capacity contributes positively, albeit weakly, to the density of population-based employment in urban FEAs only. Lodging capacity is detrimental to the population-based service economy everywhere else, particularly in rural areas (6 jobs below the national average), which means that few rural FEAs actually benefit from tourism attractiveness. The geographic effect is mainly observed in periurban areas, where it is very negative (-32). Therefore, about half the gap with the national average (-75) would be related to inherent features of these FEAs, after controlling for both the stronger propensity of their population to consume services in the nearby urban pole and their structural lack of lodging capacity. This lag in service provision could result from urban sprawl and decision makers' lack of anticipation regarding urban and facility planning in fast-growing areas. Rural FEAs structured around a job pole benefit from a slight, positive geographic effect (significant at 5\%) on the density of population-based employment, which partially corrects the negative impact of structural variables. An alternative specification excluding Paris from the urban pole category did not produce significantly different results. 
To get a more detailed perspective, shift-share analysis was applied to retailing and market services vs. administered and government services (Tables 6 and 7). Regarding the former, the highest negative gaps relative to the national average are observed, as previously, in periurban and rural FEAs. Overall, the geographic effect is very weak (even in periurban FEAs), which seems to indicate that the private sector may be more reactive in adjusting the provision of market services to changes in local demand. Among structural effects, commuting patterns play a major (negative) role, particularly in periurban areas (multipurpose trips), followed by income (also negative) in rural areas, with no structural effect of lodging capacity. Second, administered and government services tend to follow the same pattern: a strong negative effect of commuting in periurban and rural areas, followed by a negative income effect in rural areas only; the effect of lodging capacity, though statistically significant this time, remains limited. As hypothesized, the geographic effect is strongly negative in periurban areas (non significant in rural areas), indicating a lag effect for nonmarket service employment in areas that experience strong population growth. In conclusion, in periurban FEAs, it is likely that both a smaller (per resident) fiscal capacity and a lower level of intermunicipal cooperation limit investment capabilities and service provision. This result clearly raises doubts regarding the assumption that public services (quickly) follow the population and that French citizens have the same level of access to non-market services.

\section{TABLE 6 HERE}

TABLE 7 HERE

Density of tourism employment, too, varies by FEA spatial category. Several geographic effects (including ZAUER) were tested to explain the density of tourism 
employment, but the highest explanatory power of the shift-and-share model was obtained with tourism zones. Lodging capacity, fiscal potential and natural amenities are retained as structural variables. As Table 8 shows, the explanatory power of the four selected variables is fairly high $\left(\mathrm{R}^{2}=0.58\right)$. Tourism employment is strongly differentiated between tourism zones: mountain resorts exhibit an employment density that is almost four times higher than in rural areas. Such gaps are largely explained by structural effects, but there is a specific dynamics at work in mountain resorts that strongly impacts tourism employment in these areas. On the contrary, the "rural" zone presents a value for tourism employment that is significantly lower than the national average.

\section{TABLE 8 HERE}

The effect of the natural amenity index on tourism employment is significant but relatively weak as compared with lodging capacity and fiscal potential (in agreement with regression results). This, again, may be explained by differences in the spatial distribution of the amenity index (whose highest values are found in southeastern France) vs. tourism employment (more scattered across metropolitan France). It may also be explained by the overriding influence of the tourism zone variable which, by definition, captures specific recreational amenities that probably motivate travel more than climate-landscape features.

Indeed, the geographic effect is significant regardless of the tourism zone and, again, mountain resorts stand out with a high density of tourism employment (about half the density value, 66.1, is explained by the geographic variable, 30.3). Using this typology yields an a priori counterintuitive result, i.e. a negative (though weakly significant) sign for the "coast" category. Actually this result seems to show that tourism employment density in coastal areas is similar to the national average (27.6 vs. 25.9$)$ and since the lodging capacity structural 
variable grabs most of the (positive) explanatory power (followed by fiscal potential), the geographic effect (negatively) adjusts (followed by the natural amenity index) to yield the observed employment density. In conclusion, high tourism employment density is found in functional economic areas where mountain resorts are located, as illustrated by the significant and positive contribution of the "mountain resort" spatial category. This result matches BACCAÏNI et al.'s (2006) who showed that the share of tourism vs. total salaried employment is particularly high in mountain resorts. An alternative specification excluding Paris from the urban tourism category logically lowered the national average value and its gap with the urban category while increasing it for the mountain resort class; the effects of geography, lodging capacity and fiscal potential were fairly similar; the amenity variable, however, became non significant, except in rural areas: as the amenity effect is already much captured by tourism zones (e.g. water by coast), it shows up significant and positive in more “common" landscapes.

\section{CONCLUSION}

Analyzing the location of population-based and tourism services at a fine geographic scale (i.e. functional economic areas) shows heterogeneity that, broadly speaking, follows the distribution of the population according to an urban hierarchy model: the number and density of population-based jobs decreases from major city to rural area FEAs. Two dispersion effects, however, dampen agglomeration effects: the presence of resources likely to create tourism attractiveness, and political criteria that affect the location of non-market services.

First, the location of tourism jobs illustrates the dynamics at work in the service sector as well as regional development issues. Indeed, total demand for population-based services is 
dependent upon both the residing permanent population and the temporary tourism population. Enhancing local resources impacts the density of tourism jobs, which are de facto maintained by an injection of external income. Conversely, the surplus of demand generated by tourism attendance supports a level of service provision that is higher than the local consumption potential, and, by crossing ill-defined thresholds, may ensure the maintenance of various local services. On the other hand, the potential for jobs induced by tourism activities (and more broadly population-based services) in production activities that do not directly depend on the local population remains a key question.

Overall, as local impacts of tourism and recreation remain insufficiently known (not only from economic, but also social and environmental viewpoints), a key policy implication is that tourism, though often touted as systematically beneficial for the communities it affects, cannot certainly be advocated across-the-board as an economic growth and development strategy. Accordingly, further research needs consist in exploring the theoretical and empirical links between amenities, tourism activity and indicators of local economic development that include job professionalization, income distribution, and poverty.

Second, overall, administered and government service jobs are distributed more evenly across the national territory than market sector jobs. Two factors may explain this situation. On the one hand, non-market services are located according to spatial equity criteria that take account of the population's access to public services regardless of their location and local demand level. On the other hand, a lagging effect (particularly in periurban areas) could hide ongoing adjustments in services. Because of inertia, non-market jobs located in old settlement centers (whether rural or industrial) may last despite significant changes in local demographics; whereas periurban areas, characterized by more recent population growth, may not experience a short-term adjustment of public services that would be consistent with local demand changes. Therefore, research results suggest that more careful service and facility 
planning is needed to address the needs (and corresponding equity of access issues) of newcomers to periurban areas. Conversely, excess non-market services in downtown areas may be redistributed to service-lagging areas.

Three other (spatial and temporal) issues for further work may be highlighted. First, to some extent the choice of functional economic areas as the geographic scale of analysis endogenizes the relation between service location and population location. But it imperfectly accounts for the boundaries of local public action, which may be critical for population-based services via local fiscal policies and public service provision; nor does it enable an analysis of the relations that impact both population-based and productive activities. Second, analysis results showed a relatively weak explanatory power of the natural amenity variable. Further research efforts could focus on a more complete specification of an amenity index that would encompass both natural and built features so as to better reflect specific recreational amenities that are key to tourism trip decision making. Third, a time issue relates to changes in location processes. Indeed, household residential and tourism destination choices directly impact localized demand potential. However location processes also depend upon the sequence of paths that differentiate development possibilities according to choices made by both public and private stakeholders. Using indicators of both population and employment change should help explain the situation of periurban areas and improve the analysis of residential dynamics in rural areas.

Acknowledgements: This paper is based on a research project carried out by UMR Cesaer (INRA - AgroSup Dijon) and UR DTM (Cemagref, Grenoble). The project, funded by DATAR (Délégation Interministérielle à l'Aménagement du Territoire et à l'Attractivité Régionale), stemmed from DATAR's working group on regions and the service economy. An 
earlier version of this paper was presented at the annual congress of the Association of European Schools of Planning (AESOP), Liverpool, UK, 15-18 July 2009; the authors thank the participants for valuable comments and suggestions.

\section{NOTES}

1. "Population-based" aims at translating as accurately as possible the French résidentiel. Indeed, the adjective "residential" mainly pertains to housing (e.g. residential neighborhood) or health (e.g. residential treatment center) issues. Since this paper focuses on services to the population (as opposed to businesses), "population-based" was chosen.

2. Obviously some tourism-related services are more generic than others (e.g., eating at fastfood chains vs. snorkeling the Great Barrier Reef) and consequently are more likely to be found at various locations. By non tradability we mean that tourism activity is dependent upon a specific location because that location features a given attraction (regardless of its nature).

3. For technical reasons, the number of structural variables used in shift-share analysis is limited to three.

\section{REFERENCES}

ANSELIN L. (1988) Spatial econometrics: Methods and models. Kluwer Academic Publishers, Dordrecht, The Netherlands. 
BACCAÏNI B., THOMAS G. and KHIATI A. (2006) L'emploi salarié dans le tourisme: Une nouvelle estimation. Insee Première n. 1099 (August).

BERZEG K. (1978) The empirical content of shift-share analysis. Journal of Regional Science, vol. 18, n. 3, 463-468.

CEC (COMMISSION of the EUROPEAN COMMUNITIES) (2008) Green paper on territorial cohesion: Turning territorial diversity into strength. Communication from the Commission to the Council, the European Parliament, the Committee of the Regions and the European Economic and Social Committee, COM(2008) 616 final, Brussels.

CÖRVERS F., HENSEN M. and BONGAERTS D. (2009) Delimitation and coherence of functional and administrative regions. Regional Studies vol. 43, n. 1, 19-31.

DELLER S. (2010) Rural poverty, tourism and spatial heterogeneity. Annals of Tourism Research vol. 37, n. 1, 180-205.

DE SEZE B. and ARMAND L. (2005) Economie résidentielle en Ile-de-France: 1. Déterminants généraux. Etude de la DREIF/DUSD.

DIACT (2009) Dynamiques et développement durable des territoires: Rapport de l'Observatoire des territoires 2008. La Documentation Française, Paris.

DISSART J.-C., AUBERT F. and TRUCHET S. (2009) An estimation of tourism dependence in French rural areas, in MATIAS A., NIJKAMP P. and SARMENTO M. (Eds) Advances in Tourism Economics: New Developments, pp. 273-294. Physica-Verlag/Springer, Heidelberg.

DUBIN R. A. (1998) Spatial autocorrelation: A primer. Journal of Housing Economics vol. 7, n. $4,304-327$.

ENGLISH D. B. K., MARCOUILLER D. W. and CORDELL H. K. (2000) Tourism dependence in rural America: Estimates and effects. Society \& Natural Resources vol. 13, n. $3,185-202$. 
GAIGNÉ C., PIGUET V. and SCHMITT B. (2005) Evolution récente de l'emploi industriel dans les territoires ruraux et urbains: Une analyse structurelle-géographique sur données françaises. Revue d'Economie Régionale et Urbaine n. 1, 3-30.

GASCHET F. (2002) The new intra-urban dynamics: Suburbanisation and functional specialisation in French cities. Papers in Regional Science vol. 81, n. 1, 63-81.

GAULIER G. (2003) Spécialisation et productivités des régions européennes. Région et Développement $\mathrm{n} .17,161-180$.

HOUDEBINE M. (1999) Concentration géographique des activités et spécialisation des départements français. Economie et Statistique n. 326-327, 189-204.

HOYLER M., FREYTAG T. and MAGER C. (2008) Connecting Rhine-Main: The production of multi-scalar polycentricities through knowledge-intensive business services. Regional Studies vol. 42, n. 8, 1095-1111.

INRA/CNRS (2008) Base de données climatiques communales. INRA UMR1041 CESAER (F-21000 Dijon) / CNRS UMR6049 THEMA (F-25000 Besançon); after Météo France 1970-2000.

INSEE (2003) Structuration de l'espace rural: Une approche par les bassins de vie. Rapport pour la DATAR, avec la participation de IFEN, INRA, SCEES.

JAYET H. (1993) Analyse spatiale quantitative. Economica, Paris.

JENNEQUIN H. (2005) La localisation des activités tertiaires: Un enjeu économique majeur. PhD dissertation, University Paris XIII.

JENNEQUIN H. (2008) The evolution of the geographical concentration of tertiary sector activities in Europe. The Service Industries Journal vol. 28, n. 3, 291-306.

KARLSSON C. and OLSSON M (2006) The identification of functional regions: Theory, methods, and applications. The Annals of Regional Science vol. 40, n. 1, 1-18. 
KLOSTERMAN R. E. (1990) Community analysis and planning techniques. Rowman \& Littlefield Publishers, Savage, MD.

LEATHERMAN J. C. and MARCOUILLER D. W. (1996) Estimating tourism's share of local income from secondary data sources. The Review of Regional Studies vol. 26, n. 3, $317-$ 339.

LE GALLO J. (2002) Econométrie spatiale: L'autocorrélation spatiale dans les modèles de régression linéaire. Economie et Prévision vol. 4, n. 155, 139-157.

MARCOUILLER D. W., KIM K.-K. and DELLER S. C. (2004) Natural amenities, tourism and income distribution. Annals of Tourism Research vol. 31, n. 4, 1031-1050.

McGRANAHAN D. A. (1999) Natural amenities drive rural population change. USDAERS, Food and rural economics division, Agricultural Economic Report n. 781.

McGRANAHAN D. A. (2008) Landscape influence on recent rural migration in the U.S. Landscape and Urban Planning vol. 85, n. 3-4, 228-240.

MDT, INSEE (Ministère Délégué au Tourisme, Institut National de la Statistique et des Etudes Economiques) (2005) Le tourisme en France. INSEE, Paris.

MIDELFART-KNARVIK K. H., OVERMAN H. G., REDDING S. J., VENABLES A. J. (2000) The location of European industry. European Economy - Economic Papers n. 142, Commission of the EC, DG ECFIN.

NIEDERCORN J. H., BECHDOLT B. V. Jr. (1969) An economic derivation of the "gravity law" of spatial interaction. Journal of Regional Science vol. 69, n. 2, 273-282.

SCHMITT B., HENRY M. S., PIGUET V. and HILAL M. (2006) Urban growth effects on rural population, export and service employment: Evidence from eastern France. The Annals of Regional Science vol. 40, n. 4, 779-801.

SOKOL M., VAN EGERAAT C. and WILLIAMS B. (2008) Revisiting the 'informational city': Space of flows, polycentricity and the geography of knowledge-intensive business 
services in the emerging global city-region of Dublin. Regional Studies vol. 42, n. 8, 11331146.

VENABLES A. J. (1996) Equilibrium locations of vertically linked industries. International Economic Review vol. 37, n. 2, 341-359. 
Table 1. Variables used for the study (descriptive statistics per functional economic area)

\begin{tabular}{|c|c|c|c|c|c|c|}
\hline Variable & Detail & $\mathrm{N}$ & Mean & St. deviation & Minimum & Maximum \\
\hline POP_BASED & Density of employment in population-based services & 1,916 & 149.71 & 73.00 & 59.51 & $1,328.65$ \\
\hline RET_MKT & Density of employment in retailing and market services & 1,916 & 65.86 & 59.03 & 16.65 & $1,191.35$ \\
\hline ADM_GOV & Density of employment in administered and government services & 1,916 & 83.85 & 31.67 & 30.25 & 390.35 \\
\hline TOURISM & Density of employment in tourism-related services & 1,900 & 25.32 & 57.89 & 0.00 & $1,157.34$ \\
\hline MKT_SIZE & Number of people living in the pole of the FEA (in thousands) & 1,916 & 15.75 & 49.81 & 2.00 & 500.00 \\
\hline COMMUT_IN & Proportion of the workforce that enters the FEA urban area & 1,916 & 12.86 & 17.87 & 0.00 & 220.84 \\
\hline COMMUT_OUT & $\begin{array}{l}\text { Proportion of the FEA workforce that leaves the FEA of residence to } \\
\text { work in an urban area }\end{array}$ & 1,916 & 32.43 & 21.37 & 1.08 & 88.49 \\
\hline COMMUTE & $\begin{array}{l}\text { Ratio between the balance of commuters ("in" minus "out" and the } \\
\text { employed workforce per FEA }\end{array}$ & 1,916 & -19.56 & 20.41 & -77.94 & 150.32 \\
\hline INCOME & household average net income in 2003 & 1,916 & $8,418.03$ & $1,541.22$ & $5,005.96$ & $22,845.96$ \\
\hline LODG_CAP & $\begin{array}{l}\text { Number of beds in campgrounds (2005), hotels (2005) and second homes } \\
\text { (2003) relative to total population in } 1999\end{array}$ & 1,916 & 926.17 & $2,277.59$ & 0.00 & $37,875.20$ \\
\hline BLUE_COL & Proportion of blue-collar workers in the total population & 1,916 & 13.93 & 3.58 & 2.22 & 28.87 \\
\hline FISC_POT & Local tax revenues divided by the number of inhabitants & 1,916 & 545.19 & 317.64 & 201.96 & $4,673.92$ \\
\hline ACCESS & $\begin{array}{l}\text { Average access time (in minutes) from the municipalities of an urban } \\
\text { area to the urban pole of the same urban area or the closest one }\end{array}$ & 1,900 & 27.01 & 17.04 & 0.00 & 119.70 \\
\hline POP_DEN & Population density & 1,900 & 63.25 & 138.16 & 1.91 & $2,483.56$ \\
\hline NAT_SPORT & Number of nature-based sports facilities per 1,000 inhabitants & 1,900 & 3.03 & 16.55 & 0.00 & 673.78 \\
\hline FARM_AGRIF & Number of jobs (per 1,000 inhabitants) in farming and food processing & 1,900 & 136.66 & 130.62 & 2.30 & $1,402.33$ \\
\hline MANUFACT & Number of jobs (per 1,000 inhabitants) in manufacturing (save agrifood) & 1,900 & 246.11 & 193.13 & 14.81 & $4,705.29$ \\
\hline NAT_AMEN & Index based on 4 climate et landscape feature variables & 1,900 & 0.00 & 2.40 & -5.17 & 10.91 \\
\hline
\end{tabular}

Note: $\mathrm{N}=1,900$ for variables used in tourism models only 


\section{Page 35 of 44}

\section{Regional Studies}

Sources: all data from INSEE, except: NAT_SPORT (RES database, Ministry of Health and Sports); NAT_AMEN (IGN, Corine Land Cover, INRA/CNRS [2008] databases) 
Table 2. FEA employment density in population-based and tourism services according to spatial category (1999)

\begin{tabular}{lrrrrrr}
\hline $\begin{array}{l}\text { ZAUER of } \\
\text { FEA pole }\end{array}$ & $\begin{array}{c}\text { All } \\
\text { pop.-based } \\
\text { services }\end{array}$ & $\begin{array}{c}\text { of which } \\
\text { trade }\end{array}$ & $\begin{array}{c}\text { of which } \\
\text { market } \\
\text { services }\end{array}$ & $\begin{array}{c}\text { of which } \\
\text { administered } \\
\text { services }\end{array}$ & $\begin{array}{c}\text { of which } \\
\text { government } \\
\text { services }\end{array}$ & $\begin{array}{c}\text { Tourism } \\
\text { jobs }^{\mathrm{a}}\end{array}$ \\
\hline Urban pole & ${ }^{\mathrm{b}} 195$ & 41 & 40 & 87 & 27 & 27 \\
(except Paris) & ${ }^{\mathrm{c}}(46)$ & $(8)$ & $(23)$ & $(21)$ & $(11)$ & $(28)$ \\
Paris & 242 & 38 & 78 & 88 & 39 & 42 \\
Periurban & 116 & 27 & 23 & 52 & 13 & 15 \\
municipality & $(42)$ & $(27)$ & $(12)$ & $(19)$ & $(5)$ & $(31)$ \\
Rural pole & 156 & 34 & 37 & 68 & 17 & 33 \\
& $(93)$ & $(15)$ & $(71)$ & $(27)$ & $(8)$ & $(84)$ \\
Rural & 146 & 29 & 36 & 64 & 17 & 26 \\
municipality & $(73)$ & $(12)$ & $(52)$ & $(29)$ & $(8)$ & $(61)$ \\
Total & 150 & 32 & 34 & 66 & 18 & 25 \\
& $(73)$ & $(18)$ & $(48)$ & $(27)$ & $(9)$ & $(58)$ \\
\hline
\end{tabular}

Sources: INSEE, UNEDIC

Notes: ${ }^{a}$ Estimated by the minimum requirements technique

${ }^{\mathrm{b}}$ Mean

${ }^{\mathrm{c}}$ (Standard deviation) 
Table 3. Regression analysis of population-based employment density

\begin{tabular}{lrrr}
\hline \multicolumn{1}{c}{ Variables $^{\mathrm{a}}$} & $\begin{array}{c}\text { All population- } \\
\text { based services }\end{array}$ & $\begin{array}{c}\text { Retailing and } \\
\text { market services }\end{array}$ & $\begin{array}{c}\text { Administered and } \\
\text { government services }\end{array}$ \\
\hline Intercept & $\mathrm{b}_{* * * 220.2891}$ & $* * * 70.7327$ & $* * * 144.8594$ \\
BLUE_COL & $* * *-3.8020$ & $* * *-0.8138$ & $* * *-2.7562$ \\
LODG_CAP & $* * * 0.0156$ & $* * * 0.0167$ & $* * *-0.0012$ \\
COMMUT_IN & $* * * 1.2554$ & $* * * 0.7640$ & $* * * 0.4961$ \\
COMMUT_OUT & $* * *-1.5685$ & $* * *-0.6265$ & $* * *-0.8947$ \\
MKT_SIZE & $* * * 0.1187$ & $* * * 0.0574$ & $* * * 0.0668$ \\
$\lambda$ & $* * * 0.6044$ & $* * * 0.6872$ & $* * * 0.2732$ \\
N & 1916 & 1916 & 1916 \\
$L$ & -9966.52 & -9475.96 & -8856.66 \\
LM-Lag $\left(\mathrm{H}_{0}: \rho=0\right)$ & ${ }^{\mathrm{c}} 0.0002$ & 0.0001 & 0.0003 \\
Moran's I & ${ }^{\mathrm{b}}-0.0034$ & -0.0083 & 0.0007 \\
\hline
\end{tabular}

Notes: The condition index is 11.88 . Adjusted $\mathrm{R}^{2}$ values for OLS estimations were $0.61,0.62$ and 0.39 for all population-based, retailing and market, and administered and government service models, respectively.

${ }^{a}$ INCOME was dropped due to high correlation with the rate of entering and exiting commutes, itself due to the strong differentiation of urban FEAs which concentrate both job and dormitory areas. Spatial category variables were removed due to high correlation with the commuting variables upon which the ZAUER typology is partially based.

$\mathrm{b} * \mathrm{p}<0.10 ; * * \mathrm{p}<0.05 ; * * * \mathrm{p}<0.01$

${ }^{\mathrm{c}}$ Critical value for the LM-Lag statistic is $2.71(\alpha=0.1)$

${ }^{\mathrm{d}}$ Based on the residuals from the SEM estimations 
Table 4. Regression analysis of tourism employment density

\begin{tabular}{|c|c|c|}
\hline Variables & Model 1 & Model 2 \\
\hline Intercept & $\mathrm{a} * * *-24.1371$ & $* * * 37.1244$ \\
\hline LODG_CAP & $* * * 0.0116$ & \\
\hline FISC_POT & $* * * 0.0709$ & \\
\hline ACCESS & & $* * * 0.2793$ \\
\hline POP_DEN & & 0.0090 \\
\hline NAT_SPORT & & -0.0203 \\
\hline FARM_AGRIF & & $* * *_{-} 0.0417$ \\
\hline MANUFACT & & $* * *_{-}-0.0170$ \\
\hline NAT_AMEN & & 1.0870 \\
\hline$\lambda$ & $* * * 0.5216$ & $* * * 0.8708$ \\
\hline $\mathrm{N}$ & 1900 & 1900 \\
\hline$L$ & -9288.52 & -9992.63 \\
\hline LM-Lag $\left(\mathrm{H}_{0}: \rho=0\right)$ & ${ }^{\mathrm{b}} 0.0053$ & 0.1386 \\
\hline Moran's I ${ }^{\mathrm{c}}$ & ${ }^{\mathrm{a}}-0.0014$ & $* * *_{-} 0.0447$ \\
\hline
\end{tabular}

Notes: The condition index is 5.10 for model 1, 5.84 for model 2. Adjusted $\mathrm{R}^{2}$ values for OLS estimations were 0.67 and 0.05 for models 1 and 2, respectively. In model 2, some spatial autocorrelation remains despite an $85 \%$ reduction in Moran's I value from OLS to SEM estimations.

$$
\begin{aligned}
& { }^{\mathrm{a} *} \mathrm{p}<0.10 ; * * \mathrm{p}<0.05 ; * * * \mathrm{p}<0.01 \\
& { }^{\mathrm{b}} \text { Critical value for the LM-Lag statistic is } 2.71(\alpha=0.1) \\
& { }^{\mathrm{c}} \text { Based on the residuals from the SEM estimations }
\end{aligned}
$$


Table 5. Shift-share analysis of population-based employment density

\begin{tabular}{|c|c|c|c|c|c|c|}
\hline \multirow[t]{2}{*}{$\overline{\text { ZAUER }}$} & \multirow{2}{*}{$\begin{array}{l}\text { Pop.-based } \\
\text { job density } \\
\text { (/1,000 inh.) }\end{array}$} & \multirow{2}{*}{$\begin{array}{l}\text { National } \\
\text { avg. gap } \\
(196.18)\end{array}$} & \multirow{2}{*}{$\begin{array}{l}\text { Geographic } \\
\text { effect } \\
\text { ZAUER }\end{array}$} & \multicolumn{3}{|c|}{ Structural effects } \\
\hline & & & & INCOME & $\underset{\mathrm{P}}{\text { LODG_CA }}$ & COMMUTE \\
\hline Urban pole & 217.64 & +21.46 & $*+2.35$ & $* * *+4.23$ & $* * *+1.70$ & $* * *+13.18$ \\
\hline Periurban & 120.86 & -75.32 & $* * *-31.84$ & $* * *+2.86$ & $* * *-2.00$ & $* * *-44.33$ \\
\hline Rural job pole & 149.12 & -47.06 & $* *+9.82$ & $* * *_{-} 18.84$ & $* * *-6.40$ & $* * *-31.63$ \\
\hline Other rural & 135.64 & -60.54 & +5.03 & $* * *-24.20$ & $* * *-6.46$ & $* * *-34.90$ \\
\hline
\end{tabular}

Notes: Adjusted R²: 0.91; condition index: 9.25.

The gap between the average employment density by ZAUER category and the national average employment density is equal to the sum of the geographic effect and the three structural effects. For example, regarding "Urban pole": $217.64-196.18=+21.46=+$ $2.35+4.23+1.70+13.18$

$* \mathrm{p}<0.10 ; * * \mathrm{p}<0.05 ; * * * \mathrm{p}<0.01$ 
Table 6. Shift-share analysis of population-based market (retailing and market services) employment density

\begin{tabular}{|c|c|c|c|c|c|c|}
\hline \multirow[t]{2}{*}{ ZAUER } & \multirow{2}{*}{$\begin{array}{l}\text { Pop.-based } \\
\text { job density } \\
(/ 1,000 \text { inh.) }\end{array}$} & \multirow{2}{*}{$\begin{array}{l}\text { National } \\
\text { avg. gap } \\
(83.63)\end{array}$} & \multirow{2}{*}{$\begin{array}{l}\text { Geographic } \\
\text { effect } \\
\text { ZAUER }\end{array}$} & \multicolumn{3}{|c|}{ Structural effects } \\
\hline & & & & INCOME & $\underset{\mathrm{P}}{\mathrm{LODG}}$ & COMMUTE \\
\hline Urban pole & 92.58 & +8.95 & -0.06 & $* * *+2.81$ & +0.31 & $* * *+6.43$ \\
\hline Periurban & 51.74 & -31.89 & $* * *_{-} 1.08$ & $* * *+1.86$ & $* * *-1.31$ & $* * *-21.66$ \\
\hline Rural job pole & 64.00 & -19.63 & $* * *+0.96$ & $* * *_{-} 12.60$ & -1.24 & $* * *-15.40$ \\
\hline Other rural & 59.26 & -24.37 & $* *+0.77$ & $* * *_{-} 15.79$ & +0.73 & $* * *-17.07$ \\
\hline
\end{tabular}

Notes: Adjusted R²: 0.84; condition index: 9.25

${ }^{*} \mathrm{p}<0.10 ; * * \mathrm{p}<0.05 ; * * * \mathrm{p}<0.01$ 
Table 7. Shift-share analysis of population-based non-market (administered and government services) employment density

\begin{tabular}{|c|c|c|c|c|c|c|}
\hline \multirow[t]{2}{*}{ ZAUER } & \multirow{2}{*}{$\begin{array}{l}\text { Pop.-based } \\
\text { job density } \\
(/ 1,000 \text { inh.) }\end{array}$} & \multirow{2}{*}{$\begin{array}{l}\text { National } \\
\text { avg. gap } \\
(112.55)\end{array}$} & \multirow{2}{*}{$\begin{array}{c}\text { Geographic } \\
\text { effect } \\
\text { ZAUER }\end{array}$} & \multicolumn{3}{|c|}{ Structural effects } \\
\hline & & & & INCOME & $\begin{array}{c}\text { LODG_CA } \\
\mathrm{P}\end{array}$ & COMMUTE \\
\hline Urban pole & 125.05 & +12.50 & $* * *+2.94$ & $* * *+1.42$ & $* * *+1.39$ & $* * *+6.74$ \\
\hline Periurban & 69.12 & -43.43 & $* * *-21.07$ & $* * *+1.00$ & $* *-0.69$ & $* * *-22.67$ \\
\hline Rural job pole & 85.12 & -27.43 & +0.22 & $* * *-6.25$ & $* * *-5.16$ & $* * *-16.23$ \\
\hline Other rural & 76.38 & -36.17 & -2.72 & $* * *-8.41$ & $* * *-7.19$ & $* * *-17.83$ \\
\hline
\end{tabular}

Notes: Adjusted R2: 0.89; condition index: 9.25

$* \mathrm{p}<0.10 ; * * \mathrm{p}<0.05 ; * * * \mathrm{p}<0.01$ 
Table 8. Shift-share analysis of tourism employment density

\begin{tabular}{|c|c|c|c|c|c|c|}
\hline \multirow{2}{*}{$\begin{array}{l}\text { Tourism } \\
\text { Zone }\end{array}$} & \multirow{2}{*}{$\begin{array}{l}\text { Tourism } \\
\text { job density } \\
\text { (/1,000 inh.) }\end{array}$} & \multirow{2}{*}{$\begin{array}{c}\text { National } \\
\text { avg. gap } \\
(25.90)\end{array}$} & \multirow{2}{*}{$\begin{array}{l}\text { Geographic } \\
\text { effect } \\
\text { Tourism zone }\end{array}$} & \multicolumn{3}{|c|}{ Structural effects } \\
\hline & & & & LODG_CAP & FISC_POT I & NAT_AMEN \\
\hline Coast & 27.65 & +1.75 & $*_{-} 4.10$ & $* * *+7.81$ & $* * *+1.25$ & $* * *-3.21$ \\
\hline Mountain & 23.14 & -2.76 & $* * *-10.81$ & $* * *+11.24$ & $* * *-1.98$ & $* * *-1.22$ \\
\hline Rural & 17.44 & -8.46 & $* * *-6.72$ & $* * *+2.20$ & $* * *-3.99$ & +0.06 \\
\hline Mountain resort & 66.13 & +40.23 & $* * *+30.28$ & $* * *+8.83$ & $* * *+3.35$ & $* * *-2.23$ \\
\hline Urban & 30.38 & +4.48 & $* * *+6.05$ & $* * *-5.38$ & $* * *+2.61$ & $* * *+1.11$ \\
\hline
\end{tabular}

Notes: Adjusted R²: 0.58; condition index: 4.77

$* \mathrm{p}<0.10 ; * * \mathrm{p}<0.05 ; * * * \mathrm{p}<0.01$ 


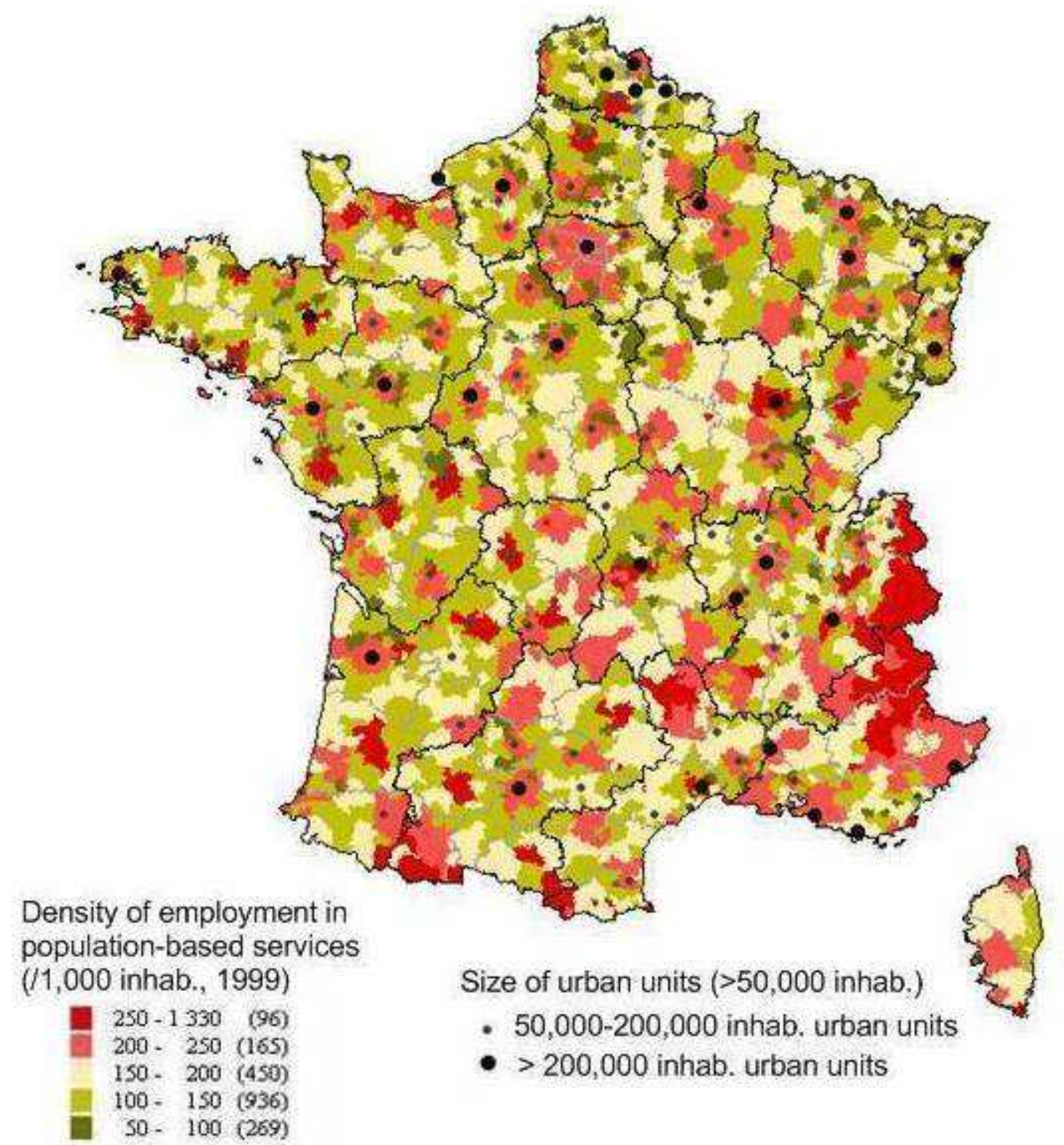

Fig. 1. FEA density of employment in population-based services (1999) Sources: IGN99, INSEE 


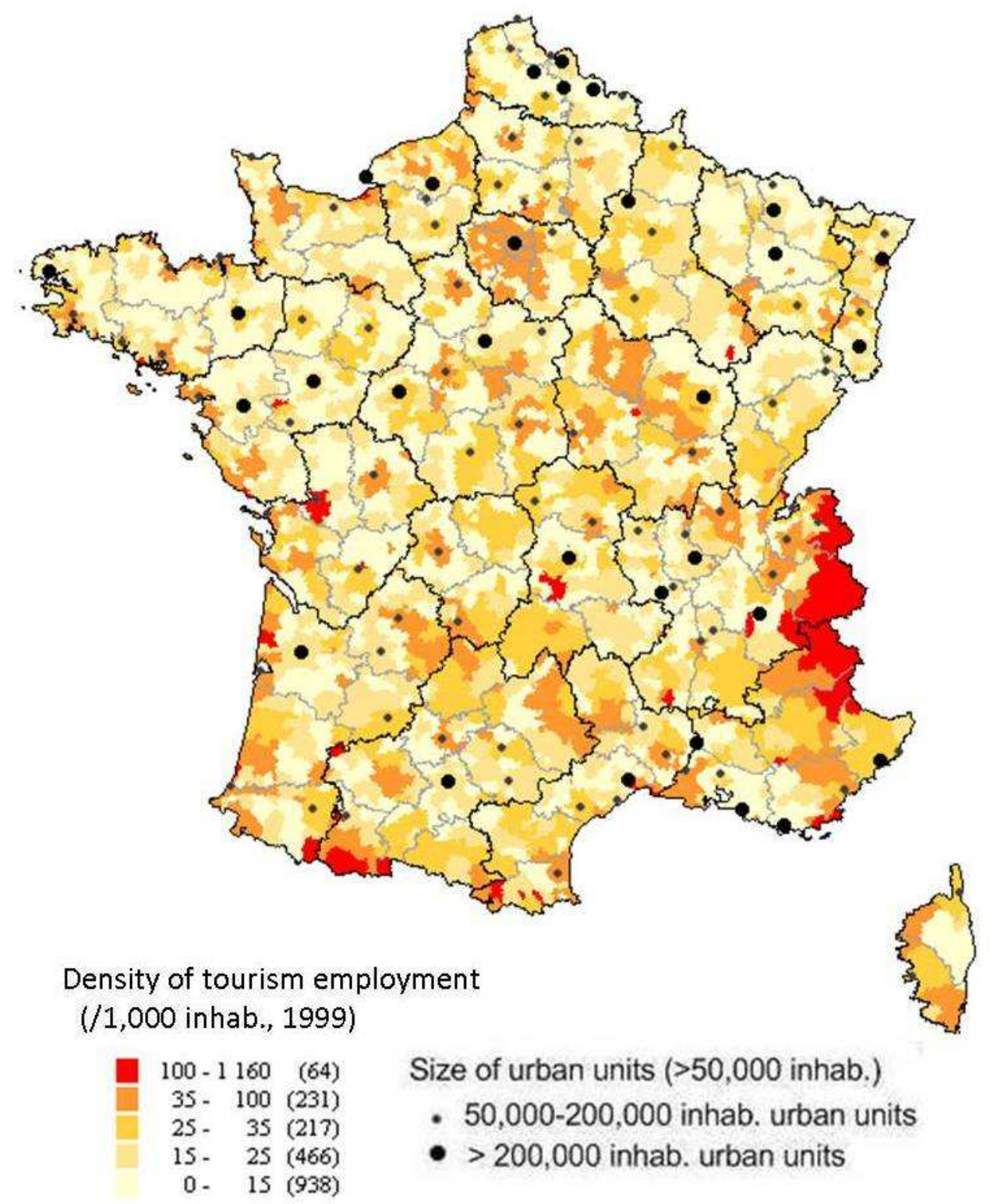

Fig. 2. FEA density of employment in tourism-related services (1999)

Sources: Authors' calculations using INSEE, IGN99 data 